\title{
So that their graves overlooked the sea: Student experience of the Philippines International Archaeological Field School ${ }^{1}$
}

\section{Melandri Vlok}

\begin{abstract}
Practical archaeological experience is essential in the training of future bioarchaeologists. This essay recounts the experience received by the author during undergraduate studies at a field school held in the Philippines. The site in Catanauan, central Philippines, provides the opportunity for students to receive training in survey, excavation, heritage work, artefact analysis and research design on real archaeological material. Furthermore, the experience encouraged independent archaeological thought and true scope in relation to the theoretical aspects of the discipline that were taught in class.
\end{abstract}

Keywords

field school, Philippines, archaeology, practical experience

1 An undergraduate course offered by the School of Archaeology and Anthropology, International Archaeological Field School (ARCH2059): programsandcourses.anu.edu.au/ course/ARCH2059. 


\section{Introduction}

To be responsible for the recovery of someone's burial, to be a part of the retelling of the story of one who came before us, is both a privilege and a rare moment of human connection where the past and present blurs into one. It is a moment that cannot be described in any way, yet it is the very reason why archaeologists and biological anthropologists excavate; I have had the opportunity to experience this very early on in my career. I attended the Philippines International Archaeological Field School in January 2013, following my first year at The Australian National University, and have been back twice since. In that time, I have grown as an excavator and a researcher; yet I attribute much of my confidence in archaeological interpretation in my undergraduate work to the practical experience I received in the field school. If nothing else, the field school placed things into perspective. When you have excavated at a real archaeological site, concepts learnt in class feel less foreign. The skills I had acquired in the Philippines field school then became foundational to my further learning.

\section{Napa site, Catanauan}

The Philippines field school, known as the Catanauan Archaeology and Heritage Project, is held at Napa site in Catanauan, on the southern border of Luzon Island. Overlooking the beach, the site is from the Metal Period dating from the 1st to 10th century CE (Vlok et al. 2017). The burials uncovered at Catanauan were predominantly placed in large earthenware jars. However, a number of extended supine burials have also been uncovered (Paz et al. 2016; Figure 1). There are eight localities present at the site, with extensive archaeological material retrieved from Localities 1 and 4 . The position of the ocean in relation to the burial site, and the presence of a shell midden overlaying the burials in Locality 1 , suggest that the ocean was important for the life-way practices of the people buried at Napa site. The 2018 season will be the 10th year of excavation at the site, indicating the extensive archaeological potential, and, along with the presence of artefacts entirely unique to the site, makes Napa a site of importance for understanding the prehistory of the Philippines and the greater Southeast Asian region in this time period. 


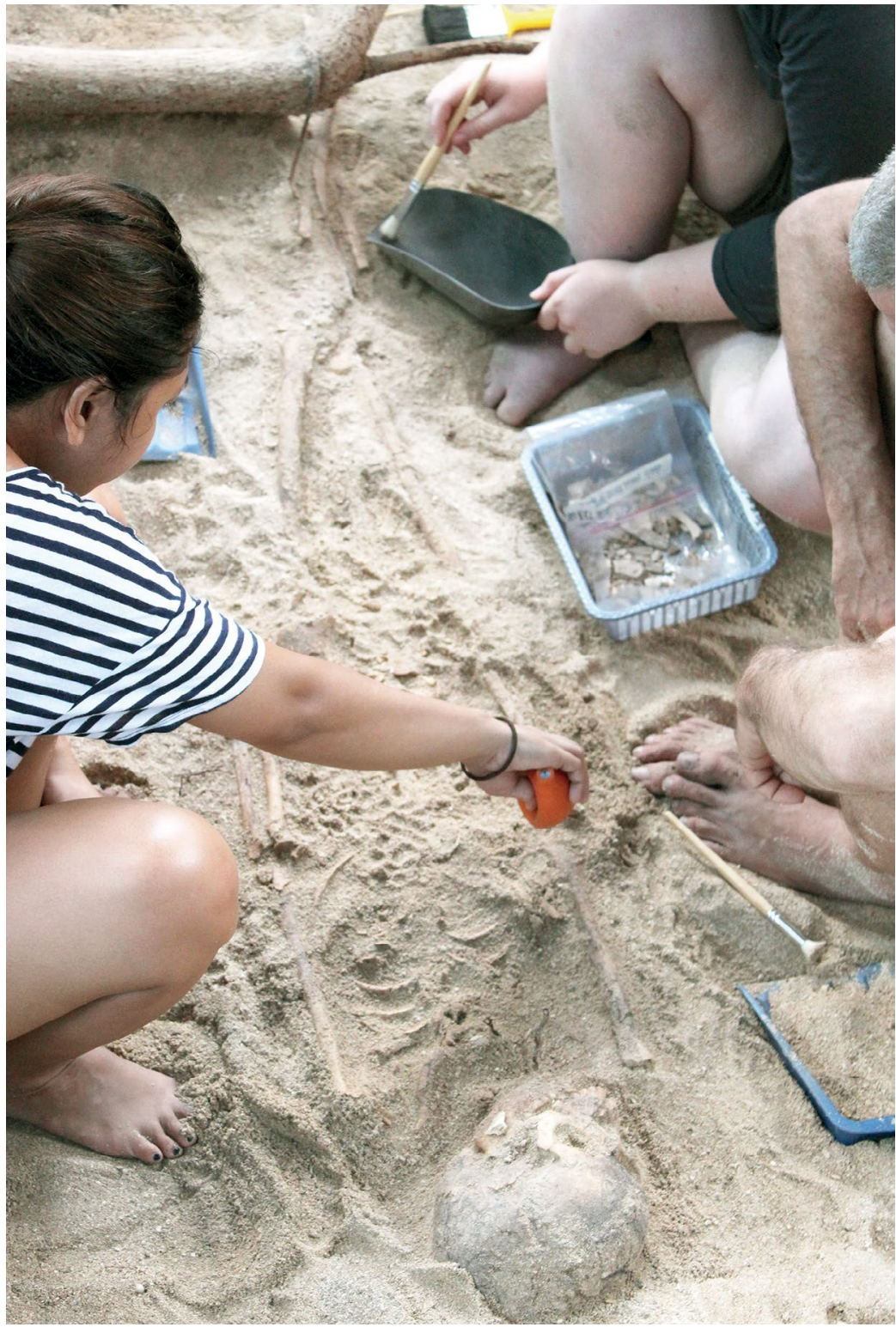

Figure 1: One of extended burials being excavated at Napa site Source: Author. 


\section{Excavation}

The excavation period of the field school runs over the course of two to three weeks, and allows all participants in the course to be involved in every aspect of the excavation. Within one field season, I experienced field walking surveys, dumpy level surveys, artefact recording, soil type identification and excavation of bone, shell, pottery and metal implements. Furthermore, I had the opportunity to engage with the local community in relation to the ongoing heritage work at the site, as well as complete museum inventory of artefacts. These aspects of excavation are often not available on field schools, yet are very important in research access and impact.

The excavation ran every day with breakfast beginning at $6 \mathrm{am}$, and everyone in the field by 7 am to beat the midday sun. By lunchtime, a midday break was taken where many caught a quick siesta in a hammock, bought snacks at the local mart called a 'sari sari store', or had a quick dip in the picturesque ocean mere metres away from the site (Figure 2). Following this, it was back to the trenches until 4 pm, where 'rounds' were held across the site and the day's happenings in the trenches were recounted so that everyone was aware of what was happening in the excavation beyond their small area.

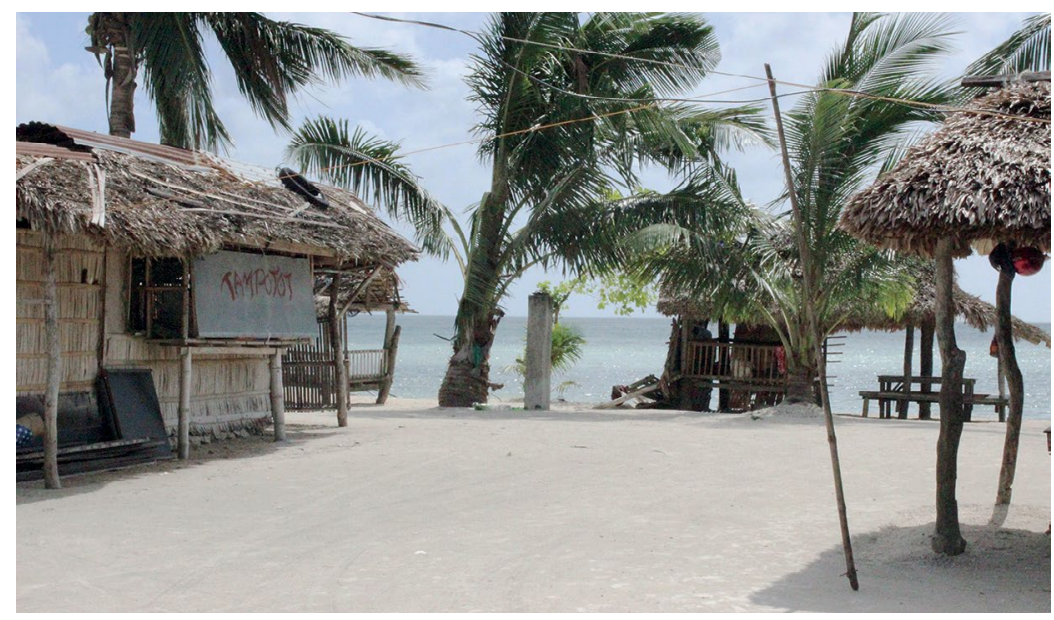

Figure 2: The site overlooks the ocean, suggesting coastal influence on the life ways of the Napa people; it is also nice for a dip during the lunch break or at the end of the day

Source: Author. 
The excavation was run in a flexible way that made it possible for us to receive more training in any aspect of excavation if we felt the need to. In this way, students were able to receive training catered to their wants and needs while also receiving general training in all areas of excavation. The nature of the cultural material at the site is diverse, and therefore attracted students with a number of different interests.

At the end of each excavation day, night-time lectures were scheduled and were aimed at expanding our knowledge of the archaeology of the greater region, as well as providing theoretical background for what was being put into practice during the day. This allowed our work to be put into the bigger context of biological anthropology and archaeology.

\section{Postexcavation artefact analysis}

Following the excavation, analysis of shell and pottery was undertaken to give us further research skills in identifying earthenware types and shell species. Once the excavation was complete, this field school offered the option of taking an extension course run during the first semester of the year. This course uses postexcavation analysis to further interpret the material and data collected. This enabled us to advance our interpretative skills and overall contributed to the narrative of the people we uncovered who had lived almost 2,000 years ago.

\section{Acquired experience}

The benefits of the field experience in the Philippines went well beyond just learning excavation skills (Figure 3). The opportunity to work alongside professionals in the field-including bioarchaeologists, archeobotanists, ceramic analysts, and geographic information system (GIS) and mapping specialists-meant I learnt from some of the best in the field. Furthermore, as the Napa excavation is a joint collaboration between The Australian National University and the University of the Philippines, the excavation provided an opportunity to work with students from a different academic upbringing, and therefore different perspectives and strengths. This only served to further expand my knowledge and skill in the field of archaeology. 


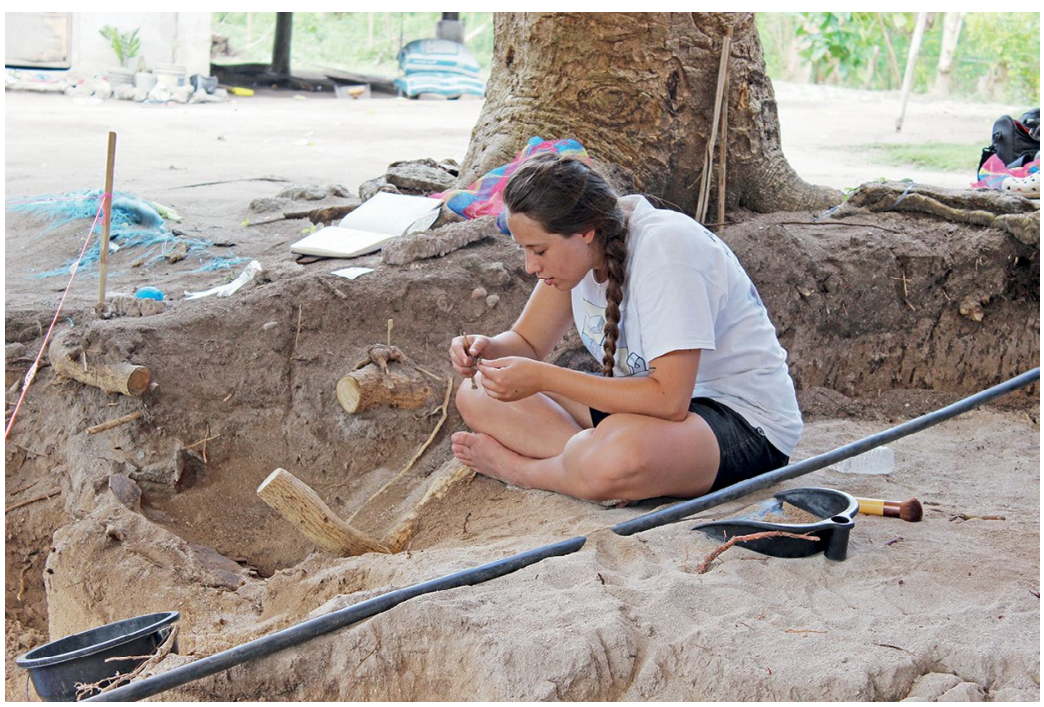

Figure 3: Melandri Vlok excavating at Napa site

Source: Bonnie Taylor.

I was always encouraged during the excavation to explore interpretations of the site, and my opinions were always considered valid. Such an environment assisted in the development of independent thought and encouraged me to think beyond the material finds and to consider the true implications of these artefacts for our understanding of the people of the past. This served to assist me in becoming a better bioarchaeologist.

Given the broad range of activities in the Philippines field school-which included surveying, excavation, heritage work, artefact analysis and research design-I was well equipped with practical experience and theoretical foundation going into my second year at university. More importantly, I approached my archaeology and biological anthropology studies with more confidence as I had a sound frame of reference given my real archaeological experience. 


\section{Acknowledgements}

I would like to thank Professor Marc Oxenham, Professor Victor Paz, Dr Rebecca Crozier, Christine Cave and Don Matthews for their continued efforts in nurturing the minds of future archaeologists at the field school. I would also like to acknowledge Ermilando Napa, Captain Leopoldo Quindoza and other members of the Barangay council of Tuhian, and the people of Tuhian, for their support of this ongoing field school.

\section{References}

Paz V, Oxenham M, Ramos J, De Castro L, Matthews D, James H, Cave C, Claravall F, Rider C, Reasonda N, Vergel D, Palconit T, Vlok M, Orizar I, Sheehan S, Katigbak G, McKenzie G, Walker M, Baker N, O’Brien D. 2016. Catanauan archaeology and Heritage Project, report on the 8th field season. University of the Philippines (Diliman): Archaeological Studies Program.

Vlok M, Paz V, Crozier R, Oxenham M. 2017. A new application of the bioarchaeology of care approach: A case study from the metal period, Philippines. Int J Osteoarchaeol. doi.org/10.1002/oa.2588 
This text is taken from the The Human Voyage: Undergraduate Research in Biological Anthropology: Volume 1, 2017, edited by Alison Behie, published 2017 by ANU eView, The Australian National University, Canberra, Australia.

dx.doi.org/10.22459/HV.01.2017.09 